\title{
History Re-Written: Misconceptions of U.S. Trade and Industrial Policy and the Influence of Neoliberalism
}

\section{Travis K. Taylor ${ }^{1}$ and Amanda Montera ${ }^{2}$}

\begin{abstract}
A disparity exists between mainstream perception and reality with regard to American economic history. There is widespread belief among the public, media, and even some scholars that the U.S. amassed its wealth and prosperity from the adoption of exclusively free-market principles from the onset of the union. This is far from reality. Since 1980, the U.S. government has adopted policies that largely support the free-market ideology and can be classified as neoliberal. However, As Chang (2002) and Cohen and DeLong (2016) have shown, during the early stages of economic development and critical junctures whilst a middle-income country, the U.S. record is one of active government intervention in targeted industries, the creation of important institutions to complement free-market competition, and the widespread use of trade protection in support of infant industries. This misconception has significant ramifications for present-day developing countries, which are routinely advised to adopt neoliberal policies with insufficient regard for the idiosyncratic stage of economic development. This paper documents the misconceptions by examining the theoretical basis and historical record of U.S. industrial and trade policy. We detail how this misconception became widespread and ultimately entered policymaking by analyzing two contributing factors: the rise of neoliberalism, and the standard economics curriculum.
\end{abstract}

Keywords: neoliberalism; American economic history; industrial policy; trade policy; economic education

JEL Codes: B1, B5, O2

Received: 31 December 2019 / Accepted: 1 March 2021 / Sent for Publication: 16 March 2021

\section{Introduction}

A great disparity exists between perception and reality when it comes to American economic history. There is widespread belief among the public, media, and even some scholars that the U.S. amassed its wealth and prosperity from strict adherence to free market principles since the onset of the union. This narrative is appealing from a theoretical and ideological perspective, but ultimately not true. In the modern era, the U.S. government has adopted policies that largely support free market ideology, though

\footnotetext{
${ }^{1}$ Corresponding author: Professor, Department of Economics, Christopher Newport University, Newport News, VA 23606 USA. E-mail: ttaylor@cnu.edu. Telephone: 1.757.594.7148

${ }^{2}$ Senior Research Assistant, Christopher Newport University, Newport News, VA 23606 USA. E-mail: amanda.montera.14@cnu.edu.

(C) 2021 by the authors; licensee Review of Economic Perspectives / Národohospodářský obzor, Masaryk University, Faculty of Economics and Administration, Brno, Czech Republic. This article is an open access article distributed under the terms and conditions of the Creative Commons Attribution 3.0 license, Attribution - Non Commercial - No Derivatives.
} 
on balance, it still qualifies as a mixed economy. As Chang (2002), Reinert (2007) and others have shown, during the early stages of economic development and critical junctures whilst a middle-income country, the U.S. record is one of active government intervention in targeted industries, the creation of important institutions to complement free market competition, and the widespread use of trade protection in support of infant industries. Drawing from the German Historical School methodology, this paper examines the economic paradigm that has fostered misunderstandings of long run development in the U.S., particularly as it pertains to industrial and trade policy.

This misconception has important ramifications for current less-developed-countries (LDCs), which are being advised based on neoliberal policies in advanced economies. In short, the types of policies undertaken by advanced economies such as the U.S. today are decidedly not the policies that were pursued when the country was at the corresponding stage of development as today's LDCs. For comparison purposes, Vietnam's current GDP per capita of \$8397 (2019 PPP; World Bank) is approximately equal to the U.S. level in the mid-1920s. China's output per person of $\$ 16,829$ is at the approximate level of France in the early 1980s. Since structural characteristics of an economy such as markets and institutions evolve throughout the development trajectory, policies suitable for one setting may perform poorly in another.

The flawed narrative is far-reaching and involves not just private citizens, but also schools (elementary, high school, college, graduate school), policy think-tanks, nongovernmental organizations (WTO, IMF, World Bank), and governments. The implication is that many recommendations for LDCs deviate from the very policies that contributed to the sustained growth of the advanced economies during their early stages of development. At best, this is callous neglect of the historical record. At worst, it could be construed as a deliberate effort to kick away the development ladder (Chang, 2002).

The paper is organized in the following way. In sections 2 and 3, we draw from economic theory to evaluate the epistemological basis for trade and industrial policy, and how it shaped the neoliberal paradigm. Next, we address a fundamental question: How did the distorted narrative become so widespread in the public domain and enter governmental and non-governmental policymaking? Here, we consider two contributing factors: the rise of neoliberalism, and the education curriculum in the United States. Section 5 offers concluding remarks.

\section{Classical Economics Revisited}

\subsection{Smith and Ricardo on Trade}

Adam Smith, a champion of free markets, departed from classical liberal doctrine in several notable areas. Smith supported the use of monetary incentives to promote strategic industrial development in England: "[Governments should implement] premiums and other encouragements to advance the linen and woolen industries" (Smith 1759, p. 185). Concurrently, in The Wealth of Nations (1776, p. 879), Smith advocated for export taxes on primary product exports such as wool to generate government revenue and incentivize manufacturing. Since manufacturing was seen as a necessary part of industrialization and development, Smith recommended "limiting free exportation of corn [to] cases of the most urgent necessity (famine)" (Smith 1776, p. 324). In fact, Great Britain did not fully 
embrace free trade until the repeal of the so-called Corn Laws in 1846. By this point, Britain had already surpassed most other countries in the early industrialization race and was the indisputable economic hegemon of the world. ${ }^{3}$ Smith argued that the United States should exploit its relative abundance (later termed "comparative advantage" by Ricardo) in agriculture and eschew any substantive industrialization policy - which might create competitors for Great Britain in the long run. However, the United States, France, Germany, and Japan (among others) ultimately followed trade policy strategies akin to Great Britain's during their formative industrialization periods of the $19^{\text {th }}$ and early $20^{\text {th }}$ centuries.

Furthermore, Smith was not averse to policies that distorted markets if the perceived benefits outweighed the costs. Interest rate price ceilings, in Smith's view, was a legitimate government policy intervention tool to guard against "investor stupidity" and increase the affordability of capital for fledgling businesses (Smith 1776, pp. 356-357). Government support of temporary monopoly, along with Smith's approval of Britain's mercantilist Navigation Acts (1651) represent significant deviations from the tenets of free market capitalism (Smith 1776, p. 464). ${ }^{4}$ Examined in totality, then, it is clear Smith was not a pure doctrinaire of laissez faire economics for trade and development as he is often portrayed in modern times.

The neoclassical narrative of unfettered free trade as an integral driver of economic development is not confirmed by careful historical analysis. Chang (2002) documents the current OECD countries' development process from the early 1800 s. He concludes that in nearly every case, some form of protection and export incentives were used to foster industrialization and growth. Contrary to policy prescriptions based on neoclassical theory, Rodrik (2009) does not find any negative correlation between tariff protection levels and economic growth in a large panel of countries. In another important paper somewhat neglected in the literature, Weisbrot et al. (2005) conducted an empirical analysis of Latin American economic growth before and after the neoclassical reforms of the 1990s. The results were surprising to some: the countries grew slower, on average, following the implementation of neoclassical policy reforms (1980-2015). At the very least, one might expect the findings of these papers to encourage further critical analysis of the nature and speed of policy reforms. Unfortunately, this has largely not been the case. ${ }^{5}$ The most widely adopted textbooks (described in section 4.1 below) and mainstream theoretical literature are still very much entrenched in the neoliberal camp.

\footnotetext{
${ }^{3}$ Scholars such as Chang (2002) and Cohen and DeLong (2016) have noted that Smith supported protectionist measures to encourage British colonies in the U.S. and elsewhere to focus on agricultural production and primary products.

${ }^{4}$ The Navigation Acts (1651-1849) restricted free trade between Britain and the American colonies. Though Smith supported it under the guise of British national defense, the Acts were fundamentally based on mercantilist trade policy. Mercantilism contends that a country's wealth is based on the accumulation of foreign exchange via trade surpluses.

${ }^{5}$ There are, of course, exceptions. Heterodox economists in the Union for Radical Political Economics will routinely speak to the shortcomings of neoliberalism. Among the most notable of mainstream economists arguing for a more nuanced approach to development include Justin Yifu Lin, Dani Rodrik, Ha-Joon Chang, and Erik Reinert.
} 
The theoretical basis for free trade is robust, and in general countries with relatively more open economies have grown more rapidly. However, as the World Economic Forum report $(2015$, p. 2$)$ argues, cookie-cutter trade policies have proven ineffective:

"[There is no] single, ideal policy or institutional mix for the pursuit of inclusive growth and development. The so-called Washington Consensus offers a roadmap for countries seeking to generate strong growth in national income in part through integration into the global economy. But its near-exclusive focus on drivers of GDP growth and relative inattention to structural and institutional features of policy that influence the extent to which growth translates into broad-based progress in living standards has rendered it incomplete and unbalanced."

The strict interpretation of, and adherence to static comparative advantage implies that it is irrelevant what a country produces and ultimately exports. Moreover, it largely obviates the role of government in fostering trade and industrialization - aside from public goods and governance. Michael Boskin, former director of the U.S. Council of Economic Advisors under President Ronald Reagan famously quipped, "I don't care whether America makes computer chips or potato chips" (Nester 1997, p. 6). This view is consistent with neoclassical theory, and neoliberal policy more broadly since the 1980s. In fact, most economics textbooks at the college and graduate school levels still fail to distinguish between static and dynamic comparative-concepts that are fundamental to understanding the role of trade in economic development.

To what extent is Boskin's statement accurate? In a static analysis, world output is maximized when countries pursue free trade policies under the Ricardian principles of specialization in the lower opportunity cost activity (comparative advantage). But from a long run development perspective, Boskin's comment is flawed; the strict assumptions of the Stolper-Samuelson theorem do not hold in the real world. The Stolper-Samuelson theorem (S-S) states that free trade will, when several strict assumptions are met, cause factor prices to converge across countries over time. In short, wages paid to labor in the tradable sectors should converge eventually. Figure 1 lists the assumptions of the Ricardian trade model and S-S theorem.

Several assumptions of S-S (and the Ricardian model) are unlikely to hold. Perfect competition and constant returns to scale production (assumptions 1 and 2) is the exception rather than the norm in most industries (agriculture is the exception). When industries are concentrated, the economic environment pivots to strategic behavior, pricing power, and increasing returns to scale. Transaction costs are certainly not zero or negligible (assumption 4) in most industries, thereby preventing the free flow of capital, labor, and information across borders. Without these assumptions, factor prices don't necessarily equalize. Davis and Mishra (2007) analyze the S-S theorem in the context of post- 1980 trade liberalization in Latin America. Since labor is the abundant resource in Latin America, S-S predicts that labor wages across countries should converge. They conclude, "It is time to declare Stolper-Samuelson dead," because wage inequality increased during the period (Davis and Mishra 2007, p.89). 


\section{Figure 1. Assumptions of the Ricardian Model and Stolper-Samuelson Theorem}

\begin{tabular}{|l|l|}
\hline Assumption & Contradiction \\
\hline A1: Perfect competition & $\begin{array}{l}\text { Many industrial market structures are } \\
\text { imperfectly competitive, with differentiated } \\
\text { goods and pricing power. }\end{array}$ \\
\hline A2: Constant returns to scale & $\begin{array}{l}\text { Imperfectly competitive industry is marked } \\
\text { by increasing returns }\end{array}$ \\
\hline A3: Labor is immobile internationally & $\begin{array}{l}\text { International immigration calls into question } \\
\text { this assumption; Autor et al. (2014) document } \\
\text { the acute costs of domestic intra-industry } \\
\text { labor movements. }\end{array}$ \\
\hline $\begin{array}{l}\text { A4: Frictionless trade (negligible transaction } \\
\text { costs) }\end{array}$ & $\begin{array}{l}\text { Transaction costs (including transportation, } \\
\text { search, organizational, coordination and } \\
\text { monitoring), while decreasing due to } \\
\text { technology, is clearly a non-trivial and } \\
\text { deciding factor for many firms. }\end{array}$ \\
\hline A5: Full employment & $\begin{array}{l}\text { In most states of the world, the economy is } \\
\text { not in full employment; role for monetary and } \\
\text { fiscal policy alters S-S. }\end{array}$ \\
\hline
\end{tabular}

Without factor price equalization, what a country specializes in and exports does in fact matter. According to Hausmann, Hwang, and Rodrik (2007), a quantifiable relationship exists between the types of goods produced in a country and its income. They conclude that "specializing in some products will bring higher income than specializing in others" (2). Of course, a less developed country (LDC) cannot produce high technology goods overnight, so care must be taken to deliberately ascend the product ladder while remaining tethered to its latent comparative advantage. To this end, Hausmann et al. (2007) and Lin (2010) advocate for prudent trade and industrial policies.

\subsection{Increasing Returns and Development}

In his book Breve Trattato (1613), Italian economist Antonio Serra argues that long run economic development depends greatly on a country's ability to specialize in production activities characterized by increasing returns. Increasing returns occur when a given increase in capital and labor yields a more than proportional increase in output. Importantly, this implies that as a firm grows, its unit costs decline and international competitiveness rises. ${ }^{6}$ In this pioneering contribution for its time, Serra analyzed the differential development trajectories of the Italian cities Venice and Naples. He found that the fundamental difference between the two economies was Venice's concentration of industry marked by increasing returns.

Marshall (1890, p. 452), writing during the marginalist revolution in economics, noted that industry differences in returns to scale warrants a differential government policy. He

\footnotetext{
${ }^{6}$ This effect can be compounded if industry spillovers and networks exist, as is often the case in so-called national champion industries.
} 
contends that government policy should provide preferential treatment for increasing returns industries and surtaxes on decreasing returns industries. ${ }^{7}$ Reinert (1996) examines the policy implications of this line of research. According to the standard neoclassical model, it is inefficient for a country to stop short of complete specialization (of a product) under comparative advantage. Indeed, this static analysis is correct in a perfectly competitive, constant returns to scale, S-S world. Since the key assumptions of S-S typically do not hold, however, a country strictly adhering to Ricardian comparative advantage will likely find itself stuck in a middle- or low-income trap. Reinert and Reinert (2003, p. 23) see this as a fundamental flaw of neoclassical theory:

If one is to operate on the abstraction level in the works of Smith, Ricardo, and Samuelson's trade theory, where production and exchange melt into the elusive concept of "labour time," one loses an entire axis of value, namely the measurement of qualitative difference among economic activities. The natural consequence of these standard assumptions of neoclassical economics is that prices of the factors of production - capital and labour - will tend to equalize under a system of free trade. It can be argued that this theorem is the very foundation of today's world economic system, and it has its roots in Adam Smith's equation of economic activities. We argue that by going back to seeing the world through the lenses of Antonio Serra, we can find the reasons why present globalisation produces such different results in different countries.

Canada and Australia grew slower than the U.S. in the $19^{\text {th }}$ and $20^{\text {th }}$ centuries but still undertook industrial policy measures to diversify their economies and create new comparative advantages. Notably, these countries (including the U.S. in the early 1800s) promoted domestic industries even if they were not internationally competitive in the static sense of the Ricardian model. At the risk of oversimplifying a complex idea, a departure from the static, neoclassical model implies that for a developing country an "inefficient lawyer is better than the world's best dishwashers" (Reinert 1996, 28-29). ${ }^{8}$

Nearly all of today's industrialized countries used a combination of trade and industrial policies to promote increasing returns industries (Cohen and DeLong, 2016; Chang, 2002). The ascendancy of neoclassical economics and neoliberalism more broadly, however, makes it far more difficult for today's LDC's to pursue similar trade and

\footnotetext{
${ }^{7}$ Irwin (1996, p. 115) provides a balanced analysis of the arguments against free trade and several prominent counters from the classical school. He concludes that while the increasing returns to scale case has merit, "the terms of trade argument appears to be the most robust and least subject to qualification or exception, and it remains the most widely acknowledged and generally accepted restriction to free trade admitted by economic theory."

${ }^{8}$ A comparison of the wage gap between baseball and golf ball manufacturing can further elucidate this point. Workers in the Dominican Republic and Costa Rica, which hold a comparative advantage in baseball production earn approximately $1 / 30^{\text {th }}$ the wage of a comparable golf ball worker in Massachusetts, USA. Controlling for several co-variates, Reinert (1996) finds that the primary reason for the wage differential is baseballs are produced in constant returns to scale firms, while golf balls are produced in increasing returns firms. A second explanation is based on the neoclassical income distribution ('spread') in baseball production versus the collusive spread in golf balls.
} 
industrial policies. Structural adjustment loans, foreign aid, and World Trade Organization (WTO) regulations require countries to reduce-and in some circumstances - eliminate many of the very policy instruments that have proven effective at fostering development. Reinert and Reinert (2003, p. 23) note the tragic irony: "The nations dominating both the successful innovation systems of the world and those activities most subject to increasing returns emptied economic theory of innovation and of increasing returns - thus removing the main cause of their own success from economic theory-first England and subsequently the United States."

\section{Industrial Policy in Historical Context}

Industrial policy refers to any form of government intervention in targeted industries with the aim of promoting select activities. The fable of American economic development holds that the U.S. - built on the purest forms of free market capitalism-has always rejected industrial policy, and it seldom played more than a trivial role. Under this narrative, private sector entrepreneurship is solely responsible for the $19^{\text {th }}$ century transformation from an agriculture-based economy-akin to Australia, Canada, and Argentina - to an industrial giant.

The reality, of course, is far more nuanced. There is some validity to the U.S.' contemporary reputation of "being the least active [among advanced economies] in the area of industrial policy" (McKay 1983, p. 29). A myriad of metrics should be analyzed to assess the veracity of such a claim. A comparison of government subsidy to industry as a percentage of GDP is one such measure. Nester (1998, p. 49) reports that explicit subsidy to industry in the U.S. is indeed relatively small ( $0.5 \%$ of GDP), and lower than other OECD members. ${ }^{9}$

On the other hand, a strong argument can be made that absent industrial and trade policy in the $19^{\text {th }}$ and early $20^{\text {th }}$ centuries, the U.S. would have industrialized slower with fewer internationally competitive industries (Cohen and DeLong, 2016; Chang, 2002). On balance, the evidence suggests that despite an absence of an overarching national industrial policy, the U.S. has successfully used many forms of ad hoc industrial policy to catalyze and complement free market capitalism.

The neoclassical paradigm rejects industrial policy as inefficient and market distorting. This rejection can be defended on theoretical grounds based on the neoclassical assumptions of perfect competition, full information, negligible transaction costs, perfect foresight, and weak barriers to entry. Moreover, detractors of industrial policy highlight the lack of empirical evidence in the literature. ${ }^{10}$ And though numerous case studies purport to show the net benefits of properly constructed industrial policy, we must be cognizant of potential selection bias with this type of methodology. Grossman (1990, p. 117) cautions, "Some of the arguments stem from the misguided belief that principles of comparative advantage do not apply in a dynamic world. More sophisticated analysts recognize that the markets provide agents with incentives to invest in the future, and so the mere likelihood of future growth is no reason in itself for governments to intervene in the process of resource allocation."

\footnotetext{
${ }^{9}$ Japan's ratio, for example, is $1 \%$ of GDP, and the European Union (EU) average is 3\%.

${ }^{10}$ See, for example, Saggi and Pack (2006) and Baldwin and Krugman (1988). 
Grossman's critique is most applicable to mature industrial economies. In this setting, markets function relatively well and industrial policy is questionable and needs to be scrutinized. LDCs, meanwhile, offer furtive ground for well-designed policy to address the failures of the market mechanism. A theoretical case for industrial policy-even in neoclassical models - can be made based on any of the following:

i) Theory of second best

ii) Economies of scale and learning-by-doing

iii) Externalities

iv) Capital market imperfections

v) Strategic trade policy

A complete treatment of i) $-\mathrm{v}$ ) is beyond the scope of this paper, but the theoretical justification for government intervention in these settings is well established in the literature. In each case, the stringent assumptions of the neoclassical model are not met, and hence industrial policy can potentially increase total welfare in the country.

\subsection{Hamilton's Industrial and Trade Policy in Early America}

Cohen and DeLong (2016) trace the origins of industrial policy in the U.S. Central to the story is Alexander Hamilton, U.S. Treasury Secretary (1790-1810), whose pragmatic vision of development helped transform a poor, agrarian economy into an industrialized power in a far shorter period than might otherwise have been possible. The Hamiltonian economic program has considerable overlap with Serra's (1613) focus on activity-specific production, and the German historical school of economics. ${ }^{11}$ In his Report on Manufacturers (1791), Hamilton's policy prescriptions include infant industry protection, tariffs, export subsidies, public infrastructure spending, vibrant financial markets, and a national (central) bank. Interestingly, Hamilton's program was initially opposed by Thomas Jefferson, who favored an agrarian-based society. Hamilton's views were regarded as incompatible with Smith and the British policies of the time, particularly after the repeal of the Corn Laws in 1846.

During the early $19^{\text {th }}$ century, the U.S. had a static comparative advantage in natural resources such as tobacco, cotton, and other agricultural products. Hamilton and U.S. Senator Henry Clay (1832) pushed for industrial policies to graduate into higher valueadded production. This was accomplished through methods such as infant industry tariffs, export subsidies, and experimentation in production methods made possible by resource inefficient allocation. ${ }^{12}$ The resulting capital to labor ratios were inefficient in the Ricardian sense, but paid dividends in the long run.

Cohen and DeLong (2016, p. 39) call America's application of the Hamilton program "resource wasting" and "innovation-forcing" for manufacturing. Resources during the Antebellum period (1815-1861) were plentiful and cheap. Coal, wood, and iron-ore, for

\footnotetext{
${ }^{11}$ Friedrich List, a prominent member of the German school, lived in the U.S. for a time and was himself influenced by Hamilton.

${ }^{12}$ In 1800, the nascent cotton, shipbuilding, and textile industries were not internationally competitive. Each industry benefited from industrial policy and became profitable. Historians cannot determine the counterfactual, but most conclude that America's $19^{\text {th }}$ century industrialization would have, at a minimum, been delayed without said policies.
} 
example, were so inexpensive firms could experiment with industrial technologies at a lower opportunity cost than other periods. Such experimentation involved picking winners (selection was often via spin-off potential), with bounties awarded for innovation and export. ${ }^{13}$ By 1880, U.S. economic performance had overtaken similar resource abundant countries like Argentina, Canada, Australia, and Ukraine, all of which were comparable to the U.S. in 1790. Industrialization was in full-force, and the economy was diversifying away from its agrarian roots - all during the $19^{\text {th }}$ century. Indeed, by 1890 the U.S. share of world manufacturing output exceeded that of Great Britain (Wright, 1990). This statist development model espoused by Hamilton set the blueprint for countries such as Japan, Germany, South Korea and much later China, to follow. Figure 2 compares the implied Hamiltonian and neoliberal development models.

\section{Figure 2. Features of the Hamiltonian and neoliberal development models}

\begin{tabular}{|c|c|c|}
\hline & $\begin{array}{l}\text { Hamiltonian (developmental } \\
\text { state) }\end{array}$ & Neoliberal \\
\hline Unit of analysis & $\begin{array}{l}\text { Industry; aggregate demand; } \\
\text { labor outcomes }\end{array}$ & Individual firm; consumer \\
\hline Markets & Imperfectly competitive & Competitive \\
\hline Institutions & $\begin{array}{l}\text { Endogenous and integral to the } \\
\text { model }\end{array}$ & Exogenous and peripheral to model \\
\hline Activities & $\begin{array}{l}\text { Heterogenous with implicit value } \\
\text { ranking for societal welfare }\end{array}$ & $\begin{array}{l}\text { Immaterial, so long as competitive } \\
\text { equilibrium obtains }\end{array}$ \\
\hline Period & Dynamic & Static \\
\hline Returns to scale & $\begin{array}{l}\text { Emphasizes the importance of } \\
\text { increasing returns }\end{array}$ & Constant returns \\
\hline $\begin{array}{l}\text { Role of } \\
\text { government }\end{array}$ & $\begin{array}{l}\text { Complementary and supportive } \\
\text { of markets and innovation }\end{array}$ & $\begin{array}{l}\text { Focus on the provision of public } \\
\text { goods; otherwise often seen as } \\
\text { combative with markets }\end{array}$ \\
\hline Protection & $\begin{array}{l}\text { Temporary for targeted infant } \\
\text { industries, market failure, and } \\
\text { terms of trade }\end{array}$ & $\begin{array}{l}\text { Inefficient and causes resource } \\
\text { misallocation }\end{array}$ \\
\hline Development path & $\begin{array}{l}\text { Industrial upgrading via latent } \\
\text { comparative advantage; } \\
\text { industrial and strategic trade } \\
\text { policy can be effective to foster } \\
\text { national champions and growth }\end{array}$ & $\begin{array}{l}\text { Strictly follow market prices to } \\
\text { determine comparative advantages; } \\
\text { capital accumulation will } \\
\text { eventually yield increased private } \\
\text { investment and growth }\end{array}$ \\
\hline
\end{tabular}

${ }^{13}$ The Springfield, Massachusetts arsenal, for instance, received government subsidies to produce guns and weaponry that used standardized parts. The aim of this policy was to increase modularity of the production process, grow the defense industry, and incentivize technological spin-offs. 


\subsection{Industrial Policy in the Post-World War II Period}

Despite the absence of a national policy, the U.S. has indeed employed a multitude of industrial policies at the state and federal levels since the early $19^{\text {th }}$ century. Figure 3 highlights some of the more common industrial policies used by the U.S., and also distinguishes between industry policy (policy targeted to a single firm and/or industry) and industrial policy (policy targeting an activity that may benefit numerous firms and/or industries). Note that the U.S.' Buy American Public Procurement Act of 1933 (amended in 1960) serves as a de facto industrial and trade policy that favors certain industries in the U.S. and creates quasi-rents for domestic firms. ${ }^{14}$

\section{Figure 3. U.S. Industrial Policy Examples}

\begin{tabular}{|c|c|c|}
\hline Type of Assistance & Industry-specific Assistance & $\begin{array}{l}\text { Industry-neutral } \\
\text { Assistance }\end{array}$ \\
\hline Supervision of markets & $\begin{array}{l}\text { Federal inspection and } \\
\text { grading of meat }\end{array}$ & $\begin{array}{l}\text { Supervision of stock market } \\
\text { (Securities and Exchange } \\
\text { Commission) }\end{array}$ \\
\hline Risk pooling & $\begin{array}{l}\text { Housing market loan } \\
\text { guarantees (Fannie Mae and } \\
\text { Freddie Mac); Fed guarantee } \\
\text { of } \$ 1.5 \text { billion loan to auto } \\
\text { firm Chrysler }\end{array}$ & $\begin{array}{l}\text { Federal Deposit Insurance } \\
\text { Corporation (FDIC) }\end{array}$ \\
\hline Research & $\begin{array}{l}\text { Land grant university funding; } \\
\text { agricultural extension } \\
\text { programs; Defense Advanced } \\
\text { Research Projects Agency } \\
\text { (DARPA) }\end{array}$ & $\begin{array}{l}\text { Tax deductions for R\&D; } \\
\text { Technology spin-offs and } \\
\text { civil application }\end{array}$ \\
\hline Input subsidies to firms & $\begin{array}{l}\text { Fire prevention and } \\
\text { suppression in national forests }\end{array}$ & $\begin{array}{l}\text { National census and } \\
\text { economic data; statistical } \\
\text { services }\end{array}$ \\
\hline Promotion of foreign sales & $\begin{array}{l}\text { Promotion of tourism industry } \\
\text { (U.S. Travel Administration); } \\
\text { Public expenditures to } \\
\text { promote U.S. fisheries }\end{array}$ & $\begin{array}{l}\text { Financing exports via Ex-Im } \\
\text { bank }\end{array}$ \\
\hline Creation of demand & $\begin{array}{l}\text { Requirement that foreign food } \\
\text { aid be shipped in American } \\
\text { flag ships (Public law 480) }\end{array}$ & $\begin{array}{l}\text { 'Buy American' public } \\
\text { procurement requirements }\end{array}$ \\
\hline Financial Assistance & $\begin{array}{l}\text { Compensation to lumber } \\
\text { workers displaced by } \\
\text { Redwood National Park; } \\
\text { Select industry assistance } \\
\text { during Covid-19 pandemic } \\
\text { (e.g., restaurant; airlines; } \\
\text { cruise ships) }\end{array}$ & $\begin{array}{l}\text { Trade Adjustment Assistance } \\
\text { (TAA) to any U.S. workers } \\
\text { displaced by factory closures } \\
\text { attributed to international } \\
\text { trade }\end{array}$ \\
\hline
\end{tabular}

Source: McKay (1983, p. 36) and authors.

\footnotetext{
${ }^{14}$ See Noorzoy (1968) for a detailed analysis of this policy.
} 
Nester (1997, p. 3) quips that "[w]hile Americans may indeed extensively practice industrial policies, they preach such mythical cultural icons as Horatio Alger who transformed himself from "rags to riches" through hard work and ingenuity unaided by others, especially the government. According to this ideal...government only impedes progress."

Tax policy, particularly after 1970, altered the prices of select resources and can be viewed as a de facto industrial policy. Special enterprise zones, preferential treatment for capital equipment, and investment credits are common instruments at the federal, state, and local levels of government. ${ }^{15}$ In the late 1970s, President Jimmy Carter called for a task force on Industrial Strategy and the creation of industrial development bank. These initiatives, however, fell out of favor during the Reagan presidency and the rise of neoliberalism in the 1980 s.

\section{The Rise of Neoliberalism and its Perpetuation}

If the popular narrative of U.S. economic history fundamentally mischaracterizes trade and industrial policy, how does it retain relevance and credibility? In this paper, we argue that two factors are particularly important to understanding this false narrative: the rise of neoliberalism in the 1980s and the current U.S. educational system.

A perfect storm emerged in the 1980s that tilted the ideological compass towards neoliberalism. First, economic stagflation in the U.S. during the 1970s and economists' failure to offer solutions was largely seen as a failure of Keynesian policy. Neoclassical economics drawing on general equilibrium models had established itself as a workhorse model of microeconomics since the 1960s. ${ }^{16}$ However, it was the contributions to macroeconomics from new classical economists in the late 1970s and early 1980s that informed many think tanks and central bank policy. The academic focus shifted to models of market-clearing equilibria, rational expectations, representative agents, and recursive optimal control methods.

The application of new classical models to public policy circles was swift. U.S. President Ronald Reagan and British Prime Minister Margaret Thatcher implemented supply-side policies to slash discretionary, non-defense spending and social welfare programs. Aggregate demand management was jettisoned in favor of tax cuts intended to stimulate business investment and labor supply. Contemporaneously, conservative think-tank organizations such as the Heritage Foundation and the Cato Institute sponsored white papers that connected theoretical contributions from new classical scholars with applied policy. Williamson's (1990) Washington consensus article is one of the more influential papers from this period. It put forth a set of policy prescriptions intended to support privatization of markets, reduced government spending, and trade liberalization.

These measures-which are generally supported by most economists-were not particularly controversial at the time. However, Williamson himself lamented in later

\footnotetext{
${ }^{15}$ Engines and turbines, for instance, can be depreciated at a rate of $30.2 \%$ compared to office computing equipment at $11.9 \%$, ships/boats at $5.1 \%$, and furniture at $6.4 \%$ (Fisher 1985, p. 6). ${ }^{16}$ Though the origins of general equilibrium theory date back to Walras' Elements of Pure Economics (1877), key proofs of competitive equilibrium and market clearing are from Arrow and Debreu (1954).
} 
work (1997) that the Washington consensus was never intended as a strict recipe for development policy. Nevertheless, neoliberals used it as a theoretical basis for policy reform in advanced economies and LDCs alike-effectively promoting a cookie-cutter approach to prosperity. International organizations such as the IMF, the World Bank, and WTO adopted this approach for much of the period (circa 1990-2009). Detailed historical accounts of these organizations cite both external and factors that contributed to the neoliberal policy bent. Woods (2006) argues that the governance structure of the IMF and World Bank is problematic because the G-7 countries can appoint and fire directors. ${ }^{17}$ And since these institutions depend, disproportionately, on funding from the G-7 it is not surprising that their policy choices generally follow neoliberalism's rise in the 1980s. Even during the Reagan administration, for example, IMF and World Bank reliance on neoliberal policies led to several costly lending errors and development setbacks in Africa (Woods 2006, p. 146). Consistent with agent-based neoclassical modeling, the heterogeneity of local culture and institutions in LDCs was largely assumed away in favor of rapid market liberalization and fiscal austerity.

This shift in policy coincided with the rise in prominence of neoliberal economists in academia and government. In a revealing anecdote, Peet $(2009$, p. 139) recalls that "the new under-secretary of the [U.S.] Treasury in the Reagan administration, Beryl Sprinkel, a protégé of Milton Friedman, immediately commissioned a study to see whether the World Bank had socialistic tendencies." Friedman and the Chicago school's impact on government policy in the U.S. and abroad was significant. His fame reached new highs in the public discourse with his popular television series Free to Choose (1980) produced by the publicly funded broadcasting station (PBS) no less - which provided a platform for tutorials on the benefits of free market capitalism.

In the 1980s, neoliberal economists had the ear of numerous governments, including China, Great Britain, and much of Latin America. In Chile, the 1973 coup that deposed Allende and installed Pinochet as president set the stage for a grand experiment in neoliberal policymaking. But long before Friedman's public lectures in Santiago (1975) on the benefits of austerity and market liberalization, the seeds were sewn at the University Chicago. Appelbaum (2019) recounts the establishment of student and faculty exchanges between select Chilean universities and the University of Chicago in 1956. University of Chicago economist Arnold Harberger brought the first group of Chilean students to the U.S., where they learned price theory and were mentored by Friedman and others. Los Chicago Boys - or the Chicago Boys as they came to be known — "talked about reforming not just Chile, but the rest of Latin America" (Appelbaum 2019, p. 259). By the late 1960s, the Chicago Boys had returned to Chile and ascended to positions of power. And although the record in Chile is mixed-reduced inflation, sustained economic growth focused on commodities, but also a relatively weak social safety net and increased inequality - the influence and legacy of neoliberalism is not in dispute.

Internal pressure to conform within the IMF and World Bank was also present. The 1980s saw the rise of a new generation of economic "technocrats that shared the same college,

\footnotetext{
17 The U.S., for example, accounts for $17 \%$ of the IMF's budget and $16 \%$ of the votes in 2020 (https://www.imf.org/external/np/sec/memdir/members.aspx). For the World Bank, the U.S.' contribution is approximately 15 percent with voting rights at 15 percent (https://www.worldbank.org/en/country/unitedstates/overview).
} 
ideology, and neoliberal solutions" (Woods 2006, p. 66). This led to a homogenization of thought within the IMF and World Bank, which created incentives for staff to draw policy prescriptions that fit the neoliberal narrative. Policy recommendations that deviated from the Washington consensus faced additional scrutiny from administrators and attendant risk for staff economists concerned about career advancement. A byproduct of the external and internal pressure was to apply a similar brand of policy tools, irrespective of country constraints. ${ }^{18}$

In economic development policy, the timing of reform can matter as much as the policy itself. Noting an alternative development model successfully engineered by the East Asian tiger countries, the Commission on Growth and Development (2008) argued that strict adherence to the Washington consensus would open LDC markets too quickly without the requisite institutions and infrastructure. ${ }^{19}$ Williamson (1999) eventually adopted a more nuanced position regarding the differential welfare effects of liberalization:

I concede that the issue is less clear in middle-income countries. However, international policy should be guided by a world welfare function, and on the global level it is certainly true that free trade can be expected to improve income distribution. One might hope that middle-income countries whose poor turn out to lose through freeing trade (a result that is by no means certain, though it cannot be ruled out) would choose to compensate them... On that interpretation, the Washington Consensus deserves to be rejected since it would indeed be of doubtful value in reducing poverty. ${ }^{20}$

\subsection{The Curriculum in Secondary and Post-Secondary Education}

The struggles of Keynesian economics in the 1970s and the political shift from liberal leaders to those embracing free market capitalism certainly contributed to the rise of neoliberalism. To understand the persistence of the false narrative with respect to American long run economic development, however, we examine the mainstream secondary and post-secondary educational curriculum in social studies and economics.

\footnotetext{
${ }^{18}$ The IMF loan conditionality requirements imposed on Mexico and South Korea in the 1990s is typical of this period. While a number of fiscal austerity and labor market policies recommended by the IMF proved to be helpful in the long run, the central criticism of "general over-enthusiasm for greater capital account liberalization" was devastating to the domestic economies (Woods 2006, p.59). Unemployment in South Korea tripled after adjustment program, and to this day many Koreans - perhaps unfairly — refer to the 1998 financial crisis as the 'IMF crisis'.

${ }^{19}$ A bit of context is useful here. America, by 1970, was at a comparable stage of development relative to the rest of the world as Great Britain was in 1840. For both countries at their respective technological frontier, the benefits of promoting trade liberalization around the world cannot be overstated.

${ }^{20}$ This speech is available at: https://www.piie.com/commentary/speeches-papers/what-shouldworld-bank-think-about-washington-consensus. The original paper included ten policy prescriptions: fiscal discipline; redirection of public expenditure priorities; tax reform (to lower marginal rates and broaden the tax base); interest rate (financial) liberalization; competitive exchange rate; trade liberalization; liberalization of FDI inflows; privatization; deregulation (in the sense of abolishing barriers to entry and exit); secure property rights.
} 
We undertook a detailed analysis of the most commonly adopted textbooks to fulfill the state of Virginia (USA) high school requirements for social studies, economics, history and civics. The textbooks in the sample are approved by the governing body of the state (Virginia Department of Education), and widely adopted by other states across the country. The review was conducted independently by each author to ensure the integrity of the data. While there exists some variation in coverage of American industrial and trade policy among the five textbooks, we can draw several conclusions.

First, each of the five texts introduces aspects of U.S. economic history at the knowledge and comprehension levels of Bloom's Taxonomy. These levels are associated with term and concept recognition, and description of fact. ${ }^{21}$ Students are introduced to various types of $19^{\text {th }}$ century tariffs $(1816,1828,1890)$ without requisite economic principles to fully grasp the objectives and unintended consequences. On the one hand, students do learn the name and key dates of significant tariff legislation. However, the curriculum stops well short of the instruction needed to develop a fuller understanding of the material. The benefits and costs of trade and industrial policy are generally not addressed, and thus students will typically be unable to proceed to Bloom's higher levels of application, analysis, synthesis, and evaluation.

Third, only minor changes to topic coverage have occurred since the 1980s, despite recent advances in such fields as of monetary policy (e.g., shadow banking and the Great Recession of 2007-2008), behavioral economics, heterodox economics. This general inertia within economics education is echoed in previous curricular studies (Weidenaar et al., 1973). Moreover, trade policy-principally through the coverage of tariffsreceives far more coverage than industrial policy.

Standard introductory economics textbooks at the undergraduate and graduate levels generally omit any substantive discussion of economic history. Principles texts, broadly speaking, introduce students to marginal analysis based on the neoclassical paradigm. ${ }^{22}$ This was not always the case. American post-secondary education prior to the 1970 s often included an overview of institutions and modern economic history. The brief inclusionoften an early textbook chapter-provided useful context that was commonly seen in the philosophy, politics, and economics (PPE) tradition from the early $20^{\text {th }}$ century. ${ }^{23}$ Advances in mathematical modeling during the post-World War II period, however, led to important contributions to general equilibrium theory and the ideas later espoused by the neoclassical and new classical schools of thought. ${ }^{24}$ As economics instruction shifted the unit of analysis towards consumer and firm optimization modeling, institutions and

\footnotetext{
${ }^{21}$ A spreadsheet detailing the industrial and trade policy coverage in the high school textbooks is available upon request from the author.

${ }^{22}$ Exceptions certainly exist, but they are seldom used in the most popular introductory and intermediate economics courses required for graduation. See, for example, Heilbroner and Milberg's (2011) The Making of Economic Society, for an excellent historically based introduction to economic principles. Benko et al.'s (2011) Economics of Strategy exposes students to the role of institutions in society and transaction cost economics, topics that are critically important to understanding microeconomics, but is all too often neglected in neoclassical texts.

${ }^{23}$ O'Hara et al. (1939), for example, includes early discussion of institutions, banking history, and a social framework of economics to provide adequate context for the reader.

${ }^{24}$ See Arrow and Debreu (1954).
} 
history received less coverage. The decline of the once-influential American institutionalist school during the second half of the $20^{\text {th }}$ century reflects this change in the economics profession.

To be clear, the standard undergraduate introductory economics textbook has evolved. While little space in a contemporary introductory or intermediate course is afforded to heterodox approaches, there has been increased coverage of socioeconomic problems such as income inequality and environmental externalities. Brazelton (1977), for example, notes these changes between the first edition (1948) of Samuelson's Economics text and his ninth edition (1973). Nevertheless, a valid criticism can be made that the profession's reliance on the neoclassical model and relative neglect of institutions and history have contributed to the distorted narrative of long run economic development in the U.S.

Graduate-level micro textbooks, such as the industry leader Mascollel, Winston and Green (MWG) provide a rigorous treatment of general equilibrium concepts derived from Arrow and Debreu (1954). Undergraduate and graduate-level macro curricula are more diverse than micro, and most economics majors gain exposure to at least a modicum of perspectives and models from the various schools of thought. ${ }^{25}$ It is notable, however, that concurrent with the rise of neoliberalism, new classical macro models based on micro foundations have commanded a greater share of many course syllabi. ${ }^{26}$

Unfortunately, the real-world applicability and empirical validity of such models proved wanting as most economists failed to predict the gravity of the 2008 financial crisis. Instead, many government and private sector economists opt for other models that, while less sophisticated in terms of the mathematics, tend to forecast better. An unintended consequence of the 2008 Great Recession in the U.S. has been the subsequent call for introspection and reform in the economics profession. Student-led groups such as Rethinking Economics (www.rethinkingeconomics.org) call for modifications to the current curriculum to foster teaching topics and methods that are more reality-based and grounded in history and empirics.

\subsection{Etymology}

The rise in neoclassical and neoliberal ideology from the 1980s to the early 2000s is correlated with a general decline in industrial policy publications over the same period. We present the results from a Ngram analysis to illustrate long term trends in the usage of these and related concepts. Ngram tabulates the frequency of usage of a word or phrase in books between 1500 and 2008. Google developed this system as a way for researchers to track the ebb and flow of words, ideas, and phrases over time. A notable caveat is Ngram's omission of journal articles and newspapers. This is an obvious limiting factor of the methodology, but we believe the sample population of worldwide books - over 500 years with a disproportionate number of scholarly publications - will accurately capture most trends in economics. Since our objective is to gauge etymologic shifts in the

\footnotetext{
${ }^{25}$ Undergraduate intermediate macro courses often expose students to tenets from the Keynesian, Classical, New Classical, and Monetarist approaches. See, for example, Gordon (2011), and Froyen (2012).

${ }^{26}$ Highly regarded texts include Mankiw (2018), Sargent (1987), and Lucas and Stokely (1989). 
professional discourse, we view Ngram analysis as complementary to the main arguments of this study. ${ }^{27}$

In the following charts (figures $4-7$ ), we track the usage of select words and phrases pertaining to free markets, neoliberalism, and industrial policy. Figure 4 confirms the increased interest - particularly after 1980 - in one of the theoretical pioneers of free market capitalism, Friedrich A. Hayek.

\section{Figure 4. Ngram of 'Hayek'}

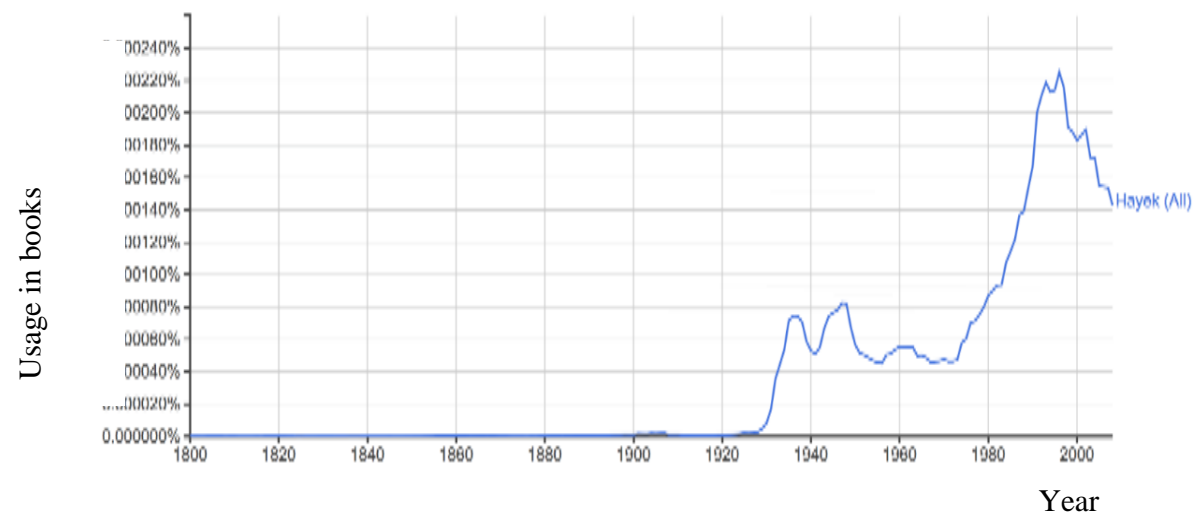

Source: Google Ngram (2020).

The y-axis label, "usage in books" refers to the frequency the word or phrase appears in books over the years provided on the x-axis. Hayek's first book, Monetary Theory and Trade Cycle (1933) accounts for much of the initial increase in usage. Each subsequent spike in the graph is consistent with a book release from Hayek. The acceleration in the 1970s may be attributed to Hayek receiving the Nobel prize in economics in 1974. In general, the Ngram frequency of Hayek coincides with the rise of neoliberalism from 1980 to approximately 2000 .

\footnotetext{
${ }^{27}$ Another minor caveat of Ngram can be noted. Ngram's algorithm limits the ability to refine a search past a certain date. Google has established special commands that help a user home in on the specific word or phrase that they are looking for, however, a user may only use one command per graph line. For example, a user may not search for all variations of a stem word and have the results be case-insensitive. Optical character recognition (OCR) errors are also very prevalent in the Ngram system. Optical character recognition is the process of taking each word from the pictures of pages from each of the million books that google sifted through. This means that Ngram could easily mix up words with similar compositions such as "case" versus "café", and "fame versus same."
} 


\section{Figure 5. Ngram of 'Neoliberalism'}

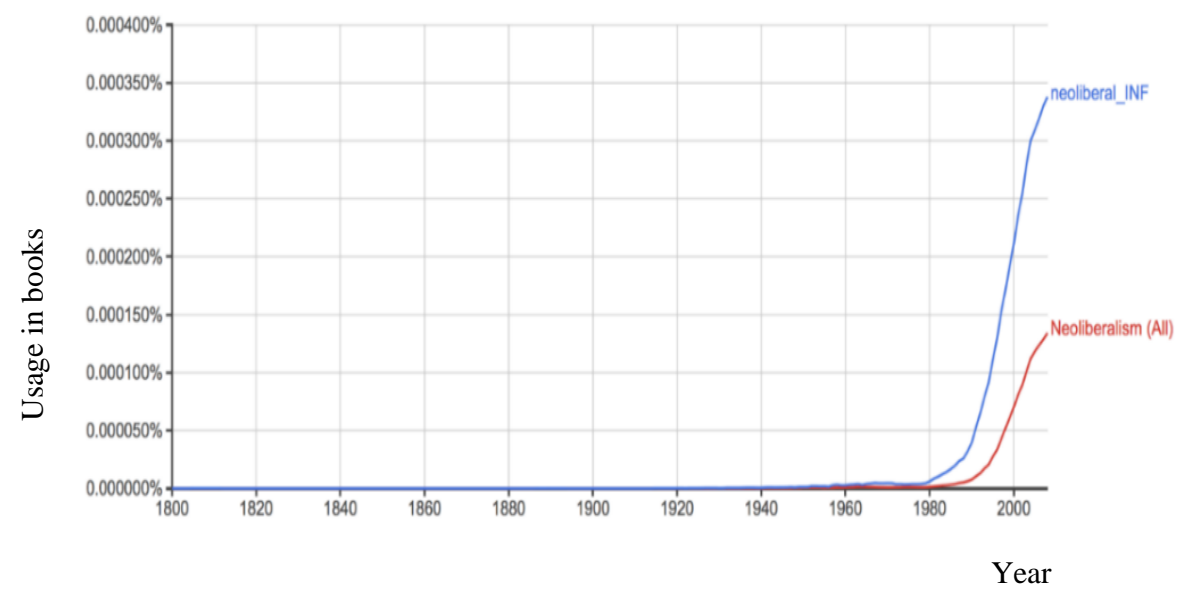

Source: Google Ngram (2020)

Neoliberalism as a term reached a critical mass beginning in the early 1980s, as seen in figure 5. To account for common variations in the use of the term, we include "neoliberal" (neoliberal_INF) and a case insensitive analysis of the word "Neoliberalism". The Ngram confirms the spectacular rise of neoliberal discourse between 1980-2000. Williamson's (1990) Washington consensus paper, often viewed as a neoliberal manifesto, clearly correlates with the literature of this time.

\section{Figure 6. Ngram of 'Washington Consensus'}

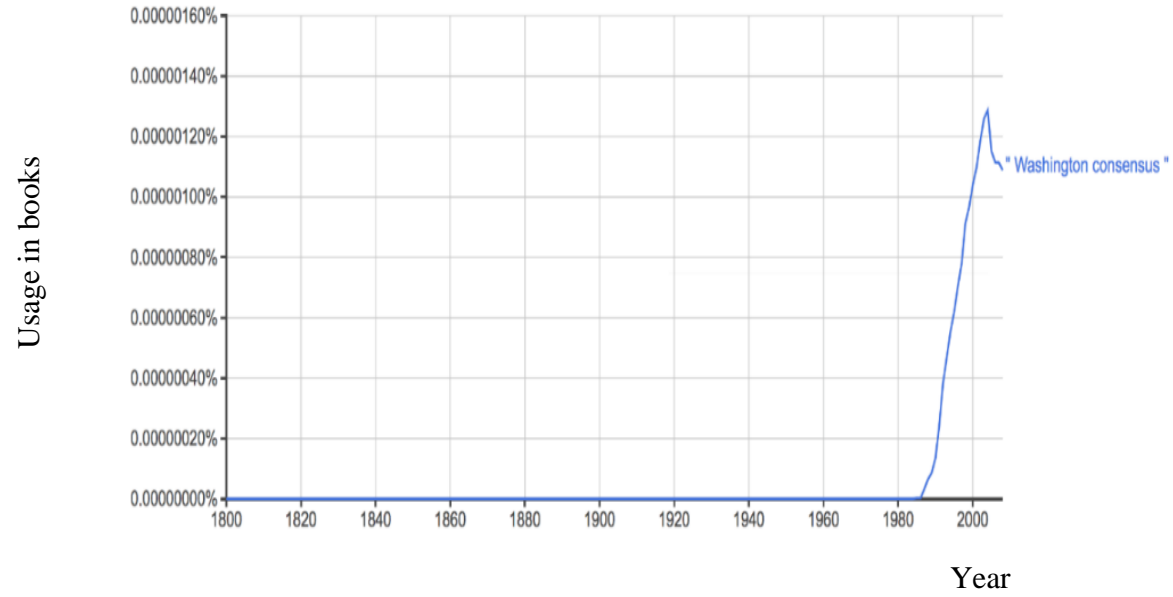

Source: Google Ngram (2020) 
The Ngrams for Hayek, neoliberalism, and the Washington consensus (figure 6) all indicate an upward trend from the mid-1970s until the mid-1990s. This trend wanes after 2000, when scholars and policymakers began to question the "one-size-fits-all" undertones of neoliberal prescriptions (Rodrik, 2009). ${ }^{28}$

During the years 1990-2010, we observe a negative correlation between the terms "free market capitalism" and "American industrial policy" (figure 7).

\section{Figure 7. Ngram of 'Free market capitalism' and 'American industrial policy'}

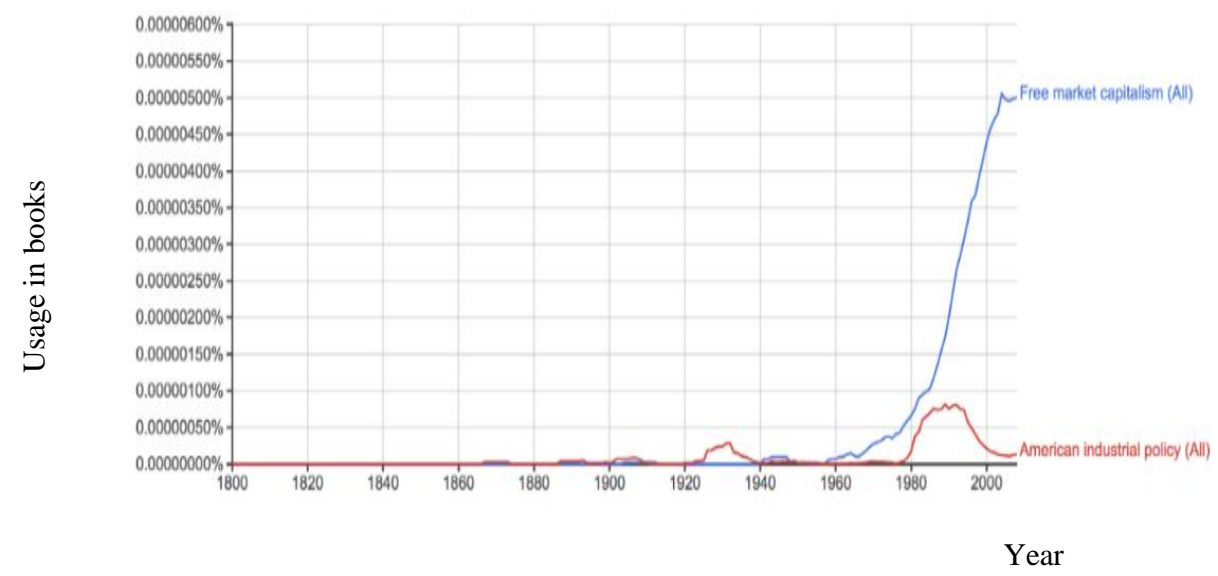

Source: Google Ngram (2020)

During this period, neoliberalism gained significant traction in academic and policy circles, and the U.S. economy enjoyed extended cycles of above average growth (19922001, 2002-2007).

The discourse of industrial policy, which has seldom been promulgated by mainstream U.S. economists and policymakers, declined even further. By 2010, however, we observe a small reversal in this trend. While it is impossible to assign causation, the financial crisis of 2008, increased inequality, and several impactful new studies on differential growth in developing countries are likely contributing factors. ${ }^{29}$

\section{Conclusion}

Schumpeter (1930, preface, p. x) once wrote, "The general reader will have to make up his mind, whether he wants simple answers to his questions or useful ones-in this as in other economic matters he cannot have both." This statement is germane to our inquiry of the government's role in fostering economic development in the United States.

\footnotetext{
${ }^{28}$ Michael Spence, Nobel prize recipient and chair of the World Bank's (2008) Growth Commission Report, argued for a 'New Consensus' that modifies the Washington Consensus to permit more policy adaptation for individual countries.

${ }^{29}$ Several important studies during this time include: Weisbrot, Baker, and Rosnick (2005), The World Bank's Commission on Growth and Development (2008), and Rodrik (2009).
} 
Government intervention - via trade and industrial policy-is nuanced and prone to oversimplification, political ideology, and populism. The fable of American economic development purports that unfettered market competition, entrepreneurial spirit, and free trade are largely responsible for the country's rapid industrialization during the $19^{\text {th }}$ and $20^{\text {th }}$ centuries. According to this narrative, the private sector and government have a limited and often combative relationship; the government ought to simply provide public goods and enforce contracts. Strategic trade and industrial policies are seen as inefficient and even inimical to the country's development goals.

In this paper, we argue that this narrative is incomplete and ultimately incorrect. Contrary to popular belief, the U.S. government implemented policies in the $19^{\text {th }}$ and $20^{\text {th }}$ centuries that fostered technology acquisition, trade, and industrialization. Indeed, the Hamiltonian economic policies and the resultant U.S. industrialization during the $19^{\text {th }}$ century have influenced scholars and governments around the world to the present day. Germany, Japan, South Korea, and China most recently have adopted aspects of the American development model to their political-economic system and institutions. Historical analysis of the economies that have successfully industrialized reveals an inescapable finding: virtually all these countries strategically used trade and industrial policy in support of, and complementary to, free markets.

Today's LDCs are often caught between a rock and a hard place. On the one hand, LDCs could benefit by gradually liberalizing the economy and improving the quality of institutions. However, international organizations such as the WTO often pressure governments to adopt such reforms rapidly - much faster than the gradualism of many Western countries during the $19^{\text {th }}$ and $20^{\text {th }}$ centuries. ${ }^{30}$ Loans, grants, and other forms of economic assistance are often contingent upon explicit or implicit acceptance of neoliberal reforms. It is certainly the case that many of the structural reforms are growthfacilitating and necessary for sustained long-term development. The institutional and cultural differences among countries, however, imply that cookie-cutter policy agendas are likely to fail. This paper has provided theoretical and historical evidence in support of this view.

How did this false narrative of U.S. economic development perpetuate itself despite an abundance of historical evidence to the contrary? We consider two factors in this paper: the rise in prominence of neoliberalism during the 1980s, and the relative lack of contextual history of trade and industrial policy in the secondary and post-secondary curriculum. The ascent of neoliberalism during the 1980s was marked by several influences: reactions to perceived failures of Keynesian economics in the 1970s (e.g., new classical economics, real business cycle theory, supply-side economics), strongly conservative political regimes, and the effectiveness of several high-profile economists from the Chicago School, most notably Milton Friedman. In our view, Friedman's

\footnotetext{
${ }^{30}$ The WTO's General Agreement on Procurement (GPA), is just one of many examples. When a country joins the WTO (and becomes eligible for subsidized loans, improved trade agreements, and so forth), it must relinquish sovereignty in trade disputes to an international court, reduce or eliminate discriminatory procurement policies, and abandon the use of local content protection. These policy tools were frequently used by today's developed economies during their industrialization phase.
} 
influence cannot be overstated as his views permeated academia, the national press, and high-level government circles.

The U.S. educational system's role in perpetuating the free market narrative of U.S. economic development is less clear. The paucity of trade and industrial policy coverage in standard economics textbooks - from high school thru advanced graduate texts-is notable and warrants further investigation. This neglect could be attributed to the complexity of the subject matter and the associated inability to convey nuances in introductory courses. However, revisions to economics and civics texts over the last century have been remarkably minor and not correlative with the neoliberal paradigm shift of the 1980s. This observation suggests that while the educational system's textbook omissions may be a contributing factor, it is likely secondary to the profound influence of neoliberalism.

Acknowledgements: The authors are grateful for the valuable comments and suggestions from the referees and the journal editor which improved the quality of the paper. Any errors or omissions are our own.

Conflict of Interest: No potential conflict of interest was reported by the authors.

\section{References}

APPELBAUM, B. (2019). The Economists' Hour: False Prophets, Free Markets, and the Fracture of Society. New York: Little, Brown and Company.

ARROW, K., DEBREU, G. (1954). Existence of an equilibrium for a competitive economy. Econometrica. 22(3): 265-290. DOI:10.2307/1907353.

AUTOR, D., DORN, D., HANSON, G., Song, J. (2014). Trade Adjustment: WorkerLevel Evidence. The Quarterly Journal of Economics. 129(4): 1799-1860. DOI: $\underline{10.1093 / q j e / q j u 026}$

BALDWIN, R., KRUGMAN, P. (1988). Industrial Policy and International Competition in Wide-Bodied Jet Aircraft, book chapter in: Trade Policy Issues and Empirical Analysis. 45-78. National Bureau of Economic Research.

BESANKO, D., DRANOVE, D., SCHAFER, S., SHANLEY, M. (2013). Economics of Strategy. New Jersey: John Wiley \& Sons, Inc.

BRAZELTON, W. R. (1977). Samuelson's Principles of Economics in 1948 and 1973. The Journal of Economic Education. 8(2): 115-117. DOI: $\underline{10.1080 / 00220485.1977 .10845445}$

CHANG, H-J. (2002). Kicking Away the Ladder. London: Anthem Press.

CLAY, H. (1832). In Defense of the American System. Senate speech in U.S. Congress. Retrieved on $30 \quad$ May, 2020 from: https://www.senate.gov/artandhistory/history/common/generic/Speeches_ClayAmerican System.htm. 
COHEN, S., DELONG, B. (2016). Concrete Economics: the Hamilton Approach to Growth and Policy. Cambridge, MA: Harvard Business Review Press.

Commission on Growth and Development. (2008). The Growth Report: Strategies for Sustained Growth and Inclusive Development. Washington, DC: World Bank. https://openknowledge.worldbank.org/handle/10986/6507

DAVIS, D. R., M. P. (2007). Stolper-Samuelson Is Dead: and Other Crimes of Both Theory and Data, book chapter in: HARRISON, A. (ed.), Globalization and Poverty. University of Chicago Press. DOI: 10.7208/chicago/9780226318004.003.0003

FISHER, P. (1985). Corporate Tax Incentives: The American Version of Industrial Policy. Journal of Economic Issues. 19(1): 1-19.

FROYEN, R. (2012). Macroeconomics: Theories and Policies, $10^{\text {th }}$ edition. New York: Pearson.

GOOGLE NGRAM (2020). Accessed 30 December 2020. https://books.google.com/ngrams

GORDON, R. (2011). Macroeconomics, $12^{\text {th }}$ edition. New York: Pearson.

GROSSMAN, G. (1990). Promoting New Industrial Activities. OECD Economic Studies. 14 (spring).

HAUSMANN, R., HWANG, J., RODRIK, D. (2007). What you export matters. Journal of Economic Growth. 12(1): 1-25. DOI: 10.1007/s10887-006-9009-4

HAYEK, F.A. (1933). Monetary Theory and Trade Cycle. Augustus M. Kelly.

HEILBRONER, R., Milberg, W. (2011). The Making of Economic Society. New York: Pearson.

INTERNATIONAL MONETARY FUND. IMF Members' Quotas and Voting Power, and IMF Board of Governors. Accessed on December 15, 2020. https://www.imf.org/external/np/sec/memdir/members.aspx.

IRWIN, D. (1996). Against the Tide: an Intellectual History of Free Trade. New Jersey: Princeton University Press.

LIN, J.Y. (2010). New Structural Economics: A Framework for Rethinking Development and Policy. Washington D.C.: World Bank.

LIST, F. (1841). The National System of Political Economy. Accessed on April 5, 2019 from: https://oll.libertyfund.org/titles/list-the-national-system-of-political-economy.

MANKIW, G. (2018). Macroeconomics, $10^{\text {th }}$ edition. New York: Worth Publishers.

MCKAY, D. (1983). Industrial Policy and Non-Policy in the United States. Journal of Public Policy. 3: 29-48. DOI: 10.1017/S0143814X00003743

NESTER, W. (1998). A Short History of American Industrial Policies. Palgrave Macmillan.

NOORZOY, M. (1968). "Buy American" as an Instrument of Policy. The Canadian Journal of Economics 1(1). 96-105. DOI: $10.2307 / 133464$ 
O'HARA, F., O'LEARY, J., and HEWES, E. 1939. Economics Principles and Problems: a Textbook for Catholic Colleges. New York: Nostrand Company.

PEET, R. (2009). Unholy Trinity: the IMF, World Bank and WTO. London: Zeb Books Ltd.

REINERT, E. (1996). Diminishing Returns and Economic Sustainability; the Dilemma of Resource-based Economies under a Free Trade Regime, In Hansen, Stein, Jan Hesselberg og Helge Hveem (Eds.), International Trade Regulation, National Development Strategies and the Environment: Towards Sustainable Development?, Oslo, Centre for Development and the Environment, University of Oslo.

REINERT, S., REINERT E. (2003). An Early National Innovation System: The Case of Antonio Serra's 1613 Breve Trattato. Institutions and Economic Development/Istituzioni e Sviluppo Economico. 1(3).

RODRIK, D. (2009). One Economics Many Recipes: Globalization, Institutions, and Economic Growth. Princeton, NJ: Princeton University Press.

SAGGI, K., PACK, H. (2006). Is There a Case for Industrial Policy? A Critical Survey. World Bank Research Observer. 21: 267-297. DOI: 10.1093/wbro/lkl001

SAMANS, R., BLANKE, J., CORRIGAN, G., DRZENIEK, M. (2015). The Inclusive Growth and Development Report. Davos, Switzerland: World Economic Forum.

SARGENT, T. (1987). Dynamic Macroeconomic Theory. Cambridge: Harvard University Press.

SERRA, A. (1613). Breve Trattato delle cause che possono fare abbondare li regni d'oro e d'artgento dove non sono miniere, con applicazione al Regno di Napoli, A Short Treatise on the Wealth and Poverty of Nations [English translation edited by Sophus Reinert (2011), Anthem Press.].

SCHUMPETER, J. (1930). Preface. In F. Zeuthen, The problems of monopoly and economic warfare (pp. vii-xiii). London: Routledge.

SMITH, A. (1759). The Theory of Moral Sentiments. London: Penguin Publishers.

SMITH, A. (1776). An Inquiry into the Nature and Causes of the Wealth of Nations. London: Penguin Publishers.

STOKEY, N., LUCAS, R., PRESCOTT, E. (1989). Recursive Methods in Economic Dynamics. Cambridge: Harvard University Press.

WALRAS, L. (1877). Elements of Pure Economics. New York: Irwin.

WEIDENAAR, D., HARRINGTON, P., HORTON, R., SHERMLS, S. (1973). Economics in Social Studies Textbooks: an Evaluation of the Economics and the Teaching Strategies in Social Studies Textbooks, High School (Grades 10-12). Joint Council in Economic Education. 1-63.

WEISBROT, M., BAKER, D., ROSNICK, D. (2005). Scorecard on Development: 25 Years of Diminished Progress, CEPR Reports and Issue Briefs 2005-30, Center for Economic and Policy Research (CEPR). 
WILLIAMSON, J. (1990). What Washington Means by Policy Reform, in J. Williamson, ed., Latin American Adjustment: How Much Has Happened? Washington, D.C.: Institute for International Economics.

WILLIAMSON, J. (1997). The Washington Consensus Revisited, in EMMERIJ, L. ed., Economic and Social Development into the XXI Century (Washington: Inter-American Development Bank).

WILliAMSON, J. (1999). What Should the World Bank Think About the Washington Consensus? Peterson Institute for International Economics. Accessed on July 5, 2019: https://www.piie.com/commentary/speeches-papers/what-should-world-bank-thinkabout-washington-consensus.

WOODS, N. (2006). The Globalizers: the IMF, the World Bank, and their Borrowers. Ithaca, NY: Cornell University Press.

WORLD BANK. The World Bank in the United States. Accessed on December 15, 2020. https://www.worldbank.org/en/country/unitedstates/overview.

WRIGHT, G. (1990). The Origins of American Industrial Success, 1879-1940. American Economic Review. 80(4): 651-668. 